\title{
Review of Mutual Funds Investment in India
}

\author{
Govindappa Mani ${ }^{a}$, Dr. Gajraj Singh Ahirwar ${ }^{\text {b }}$
}

\author{
${ }^{a}$ Research Scholar, Dept. of Commerce, \\ Sri Satya Sai University of Technology \& Medical Sciences, Sehore, Bhopal Indore Road, Madhya Pradesh, India \\ ${ }^{\mathbf{b}}$ Research Guide, Dept. of Commerce, \\ Sri Satya Sai University of Technology \& Medical Sciences, Sehore, Bhopal Indore Road, Madhya Pradesh, India
}

Article History: Received: 11 January 2021; Accepted: 27 February 2021; Published online: 5 April 2021

\begin{abstract}
The Indian mutual fund's industry, which started its excursion with the foundation of the Unit Trust of India in 1964, has seen unobtrusive development lately. There has been developing both regarding AUM just as the assortment of items advertised. As on December 2015, the investors in India have a choice to look over in excess of 1,000 of mutual funds plans spread across 44 fund houses with a complete AUM estimation of '13.46 lakh crores. The passage of unfamiliar players has prompted the presentation of an assortment of inventive items to suit the developing necessities of Indian investors. The Indian mutual fund's industry was discovered to be overwhelmed by institutional investors.
\end{abstract}

\section{Introduction}

Mutual funds should be the best method of investment in the capital market since they are extremely cost useful and straightforward, and don't need an investor to sort out which securities to put into. A mutual fund could just be portrayed as a monetary medium utilized by a gathering of investors to build their cash with a foreordained investment. The duty regarding putting the pooled cash into explicit investment channels lies with the fund chief of said mutual fund. In this manner investment in a mutual fund implies that the investor has purchased the portions of the mutual fund and has become an investor of that fund. Enhancement of investment investors can buy securities with much lower exchanging costs by pooling cash together in a mutual fund as opposed to attempt to do it all alone. Anyway the greatest bit of leeway that mutual funds offer is broadening which permits the investor to spread out his cash across a wide range of investments. Subsequently when one investment isn't progressing admirably, another might be doing taking off, consequently adjusting the risk to benefit proportion and extensively covering the general investment. The best type of expansion is to put resources into numerous securities instead of in only one security. Mutual funds are set up with the exact target of putting resources into different securities that can run into hundreds. It could require a long time for an investor to research on this sort of scale, however with investment in mutual funds this should be possible very quickly.

The mutual fund industry is a quickly developing area of the Indian capital and monetary markets. They have become significant vehicle for activation of reserve funds, particularly from the little and family savers for investment in the capital market. Mutual funds entered the Indian capital market in 1964 so as to give the retail investors the advantage of expansion of risk, guaranteed returns, proficient management. From that point forward they have filled incredibly regarding number, size of tasks, investor's base and degree. The progression, privatization and globalization measures embraced by the Government of India opened the route for the passage of private area and unfamiliar players into this industry. Thus, this has arisen as a profoundly serious monetary assistance industry today.

A Mutual Fund is a trust that pools the saving of various investors who share a typical monetary objective. The cash in this manner gathered is then invested in capital market instruments, for example, offers, debentures and different securities. The pay procured through investments and the capital appreciation acknowledged are shared by its unit holders with respect to the most reasonable investment for the everyday person as it offers a chance to put resources into an enhanced, expertly oversaw crate of securities at a moderately ease.

\section{Mutual Fund Investor}

An investor is any gathering that makes an investment. Expansive of talking, an individual can utilize his pay in three other options. They are saving, investment and consumption. On the off chance that he saves more, at that point he should lessen on his costs and the other way around. To meet the current and future monetary prerequisite of the individual, a correct blend of these is fundamental. This is the thing that we mean by investor investment example and accordingly comes the need of mindfulness activities for this idea. An investor has numerous articles for doing the investment some are doing investment for security reason some are accomplishing for exceptional yield reason and some for tax breaks. Same pay and age bunch individuals follow distinctive example of investment and to comprehend this example is extremely perplexing. The choices for contributing our investment funds are persistently expanding, yet each and every investment vehicle can be effortlessly arranged by three fundamental qualities - security, pay and development - which likewise compare to 
kinds of investor goals. While it is feasible for an investor to have more than one of these destinations, the accomplishment of one should come to the detriment of others.

\section{Investment in Mutual Fund}

Mutual funds regularly come out with a commercial in papers distributing the date of dispatch of the new plans. Investors can likewise contact the specialists and merchants of mutual funds who are spread everywhere on the country for vital data and application structures. Structures can be kept with mutual funds through the specialists and merchants who offer such types of assistance. Nowa-day, the mail depots and banks likewise appropriate the units of mutual funds. Nonetheless, the investors may kindly note that the mutual funds plans being marketed by banks and mail depots ought not be taken as their own plans and no affirmation of profits is given by them. The lone part of banks and mailing stations is to help in appropriation of mutual funds plans to the investors. Investors ought not be diverted by commission given by specialists/wholesalers for putting resources into a specific plan. Then again they should consider the history of the mutual fund and should take target choices. Non-inhabitant Indians can likewise put resources into mutual funds.14Necessary subtleties in this regard are given in the offer archives of the plans. An investor should consider his risk taking limit, age factor, monetary position, and so on As of now referenced, the plans put resources into various sort of securities as uncovered in the offer reports and offer various returns and risks. Investors may likewise counsel monetary specialists prior to taking choices.

\section{Literature Review}

Abey (2017) - The paper contemplated the different elements impacting investment choice in mutual fund plans. It found that age and instructive capability doesn't influence the investment disposition. The paper shows that transient investment period is more liked than to hang tight for exceptional yield at cost of high risk. The paper upheld for mutual fund investments for better enhancement. Retirement pay plans are more liked by investors relying on their assignment or pay level. The expert management framework additionally impacts mutual fund investment choices as investment portfolios by giving applicable monetary data.

Afshan (2013) - The scientist examined the exhibition of mutual fund profit and development plan under the fair class for the year 2009 - 2012. The investigation found the over execution of funds and even ideal proficiency of a portion of the plans. Notwithstanding, it has been likewise discovered that a few funds, which are $100 \%$ proficient under BCC (Banker, Chances, Cooper) model are not same under CCR (Charmes, Cooper, Rhodes) model and SBM (Slacks-Based Measure) model. This shows the strength of CCR and SBM models for estimating specialized proficiency of a fund. The paper in by and large demonstrates expanded proficiency for profit and development plan funds after some time.

Agarwal et al (2017) - The paper has done an examination on 100 mutual funds for a period of time of a long time from 2013-2016. The 100 funds incorporate a mix of broadened value plans, charge saving plans, enormous cap funds, long haul blame funds, long haul pay funds, momentary pay funds, little mid-cap funds and super transient funds. Their examination uncovers the outperformance of $90 \%$ plans, particularly long, short and super short obligation funds, ELSS and mid/little cap funds. It has additionally been discovered that Valued at Risk for value based mutual funds is higher than obligation funds. Additionally, value funds draw in more cost proportion than obligation funds because of greater management exercises. Nonetheless, it is additionally redundant that low cost proportion funds will give a low return. The examination likewise announced that the fund's return may differ inside a similar classification. It might fluctuate as per an arrangement of various plans.

Aizenman, et al (2016) - The scientist contemplates the impact of efficient risk on the exhibition of worldwide mutual fund investments. The forthcoming outpouring of funds has a lower orderly risk as it decreases fund size. During emergency time of the monetary market, this impact might be proportionately enormous. With more surge of fund size, the fund administrators become more cautious in holding more fluid resources lessening the fund-explicit risk. The paper considers that there is a non-direct connection between the imminent progression of funds and precise risk commitment.

Alamelu et al (2017) - The analysts firmly contended the idea of Systematic Investment Plan (SIP) for retail investors as a cutting edge and unrivaled investment road. The paper proposed risk taker investors to go for a little and mid-cap value fund. Additionally, value mutual fund plans are appropriate for such investors who can contribute just with a low sum. It has been discovered that enormous cap value development funds give less return in long haul when contrasted with little and mid-cap, Tax saving fund plans. Because of less risk, the funds get back to be low. During their investigation, ICICI, Reliance, and UTI offered value plans are found to give preferable returns over different funds.

Baliyan et al (2017) - The creator assessed the presentation of foundation mutual funds in India. A short examination has been made between HDFC mutual fund, Reliance mutual fund, ICICI Prudential mutual fund, Birla Sun life mutual fund, UTI mutual fund, and SBI mutual fund. The creator discovered HDFC and ICICI mutual fund to be safer and Birla sun life mutual fund as better entertainer. Nonetheless, their figurings show that Reliance mutual fund is high riskier. The creators express the requirement for promoting efforts by Reliance. 
Further, the investigation expresses that public organization's funds are more liked because of security and less risk. For a similar explanation, obligation funds are likewise sought after than value based funds.

Bandi (2017) - The paper examines the insight and conduct of specialists and counsels with respect to investment in mutual fund's Micro SIP. It incorporates investment design, stock selectivity, selling revenue for Micro SIP, monetary consideration and financial improvement of mutual fund industry. It has been discovered that larger part of specialist offer a wide range of administration, still, $10 \%$ offer either value obligation funds and5\% specialists practice just in duty saving plans. Month to month assortment premise is generally liked by specialist than day by day, week by week or yearly premise. Additionally, the greater parts are keen on the offer of Micro SIP, yet at the same time there is some level of specialist who is reluctant for same. Concerning of Micro SIP, greater part position of investors gives a positive reaction. Another reality has been uncovered that specialists will offer Micro SIP for their own advantage as well as for financial turn of events. It has been accounted for that limit of specialists sells mutual fund plots when contrasted with dealers of securities, protection arrangements and Ponzi plans. Fewer specialists are discovered to be a merchant of RD and FD in the financial area. It likewise demonstrates that advancement is exceptionally continued in mutual fund area than in banking and protection area.

Banerjee et al (2017) - The paper considers the different components influencing investment choices of people. It is discovered that investors of current investment roads have the instructive and expert foundation. Just $10 \%$ $25 \%$ of complete investment funds are invested in the mutual fund, and furthermore they anticipate $15 \%-20 \%$ of the profit for their investment. 30-50 years of people are keen on specialized investment design. Youthful investors are risk takers. Open-finished plans are more liked than close-finished plans. Alongside fund, organization notoriety and fund supervisors history are likewise a significant determinant for investment choices. Market-situated investments with normal pay likewise impact investments.

Chaudhury et al (2014) - The paper read the investors' inclination for mutual funds. Private representatives and Government workers are discovered to be intrigued while the most un-intrigued investors are from the horticultural area. Financial balances fund to have mastery over mutual fund investment. Exceptional yield with okay is the overall supposition of each investor. Yet, trust and certainty over fund supervisor, fund plan, and resource management organizations additionally influence investment choice. In this sense, UTI, SBI, ICICI, and Reliance offered mutual funds are liked by the majority of the investors. Value based funds hold greatest inclination followed by adjusted funds and afterward obligation funds. Monetary counselors found to have a unique job impacting investors. For the explanation, the specialists educate for the legitimate proper preparing with respect to Individual monetary counsels. It is likewise recommended to focus on completely fixed salaried individuals as they can put resources into SIP on customary premise.

Dodiya (2015) - The scientist contemplated the different segment factors influencing investment choice in mutual fund area. The investigation was done in Ahmedabad city of Gujarat. The examination uncovers that the re-visitation of be a first concern while mutual fund investment and adaptability were having least need. Furthermore, straightforwardness and reasonableness additionally discovered successful in investment. Other than age likewise matters for impacting investors on the grounds that the examination discovered most of investors to be in age until 45 years while over 45 years age individuals are less mutual fund investors. It shows that as an individual develops more seasoned, their risk taking mentality decreases and adolescents are more inclined to risk with the impetus of a better yield. Pay level is additionally significant determinant to affect mutual fund area as the investigation reports that most extreme investors hold fine pay level while low-pay level people fears to enter to mutual fund risk because of their less discretionary cashflow. However, the paper has likewise discovered that independent of any instructive capability, an individual is prepared to put resources into mutual fund industry in the event that they have great pay and with a special case of a sound return.

Dwivedi (2016) - The paper plans to consider the impact of 2008 financial emergency on mutual fund investment market. It uncovered that there are essentially five free causes which influences investors choice with respect to continuation/discontinuance of mutual fund investment, for example, investors' pay, time viewpoint of investment, risk demeanor of investors, past returns and level and wellspring of data. The examination found that big league salary investors proceeded to investor in mutual fund because of the utility hypothesis. As to point of view, those investors proceeded to mutual fund who didn't expect any further liquidity emergency in their short run. The investors who are risk loath ended with mutual fund in dread of misfortune for too high risk in capital market. Past returns of mutual fund additionally impacts the investors as though they are exceptionally fulfilled they proceed to mutual fund investment because of their certainty while less fulfilled investors will promptly pull out themselves. The investors who have clean data with respect to idea and advantages of mutual fund, types, fund administrators, load structure, general financial design will proceed to mutual fund industry.

Gandhi et al (2016) - The investigation discovered CanaraRobeco Equity Tax saver development plans as safer, among other duty saving plans. The tax reductions offered by various plans draw in numerous investors towards mutual fund industry. Annuity conspires likewise pull in as it offers charge concessions to more established individuals. The above plans are additionally found to have high data Ratio which shows the high productivity of those fund administrators. 
Garg et al (2014) - The investigation holds the time frame 2008 - 2013 and found that chose ELSS plans performed in a way that is better than enhanced and sectoral funds in mutual fund market. In any case, it has been additionally discovered that chosen plans and market didn't remunerate sufficiently even to cover sans risk return and all out risk of the plan. Just DSP BLOCK ROCK Tax saver, Franklin India Tax shield and ICICI charge saving plans discovered to be a correct track during the examination time frame.

Godase et al (2015) - The paper fund less return of enormous cap value development funds than little and midcap, charge saving fund plans and value fund conspires because of the positive relationship of risk and returns, the risk of huge cap funds are additionally less. In this manner, tees funds are entirely reasonable for less risktaking investors. Additionally, value based mutual funds through SIP, is likewise totally reasonable for investors who are inadequate with regards to single amount add up to contribute, at a time. A few plans of SBI, UTI, ICICI and Reliance are encouraged to be invested. Notwithstanding, plans for risk takers and risk avoiders are accessible in the mutual fund industry.

Goel et al (2014) - The paper mirrored an outline of Indian mutual fund area and its new patterns. There is the consideration of numerous unfamiliar mutual funds in the Indian market. Numerous consolidations and acquisitions have been confirmed. Indian mutual fund industry is developing at CAGR of $15 \%$. The quantities of mutual fund records and exchanges have likewise expanded. In any case, the commitment of AUM towards GDP is just $5 \%-6 \%$ which is altogether lower than numerous economies. The development of obligation funds is discovered to be above then pay, adjusted, ETF, and Overseas funds. On this premise, the specialists close degree that obligation securities in the capital market are consumed by mutual fund area, to a huge degree. The paper likewise focuses at certain difficulties like absence of monetary instruction and mindfulness and so on For better and compelling dissemination channel, banks and IFAs are being recommended. An administrative routineness system is likewise being recommended to set up.

\section{CONCLUSION}

Mutual fund industry in India is arising as an observable monetary assistance which is reliably adding to the Indian monetary market to a huge degree. Despite the fact that it was set up in India in 1963 by UTI, yet the advancements have been seen in most recent couple of years as it were. General individuals set aside effort to acknowledge and embrace any new innovation. Agricultural nations like India are significantly more inflexible than created nations in regard of innovation and society. Individuals were utilized to the customary methods of investment. However, step by step with the appearance of present day monetary guides, the foundation of administrative specialists, government uphold and monetary establishment's drives, individuals are currently tolerating and tending towards mutual fund investment.

\section{References}

1. AbeyJoji, "Mutual Fund: Investors Perception on Investment", International Journal of Sciences: Basic and Applied Research (IJSBAR), Volume 34, No. 3, Pp. 55-67, ISSN 2307 - 4531, 2017.

2. Agarwal Shivangi and MirzaNawazish, "A Study on the Risk-Adjusted Performance of Mutual Fund Industry in India”, Review of Innovation and Competitiveness, Vol. 3, Issue 1, 2017

3. Agrawal Gaurav and Jain Mini, "Investor's Preference towards Mutual Fund in Comparison to other Investment Avenues", Journal of Indian Research, ISSN: 2321 - 4155, Vol. 1, No. 4, Pp - 115 -131, October - December 2013.

4. Alamelu. K. and Indhumathi. G., “Analysis of Sip Investments of Mutual Funds In India”, International Journal of Economic Research, Vol. 14, ISSN: 0972-9380, Available at Http: www. SerialJournal.Com, Nov. 2017

5. Anis Ali and BajpaiSaurabh, "Risk Opportunities and Returns for Investors in Mutual Fund", International Journal of Technology Management and Humanities, Vol.1, Issue 4, ISSN. 2454-566x, March 2016

6. Aratrika Deb, "Asset Management Companies and Their Growing Importance in the Field of Investment", Corporate Law Reporter.Com, The Daily Journal, 17 March 2015

7. BaliyanMeenu and RathiPunjika, "Performance Evaluation of Emerging Mutual Fund", Scientific Society of Advanced Research and Social Change (SSARSC) International Journal of Management, Vol. 3, Issue 1, ISSN 2349 - 6975, , Jan - June 2017.

8. Bandi Swati “The Mutual Fund Industry: A View of Agents and Advisors on Micro Sip's (Systematic Investment Plan)", International Journal of Engineering Technology Science and Research (IJETSR), Vol. 4, Issue 9, ISSN: 2394-3386, Sep 2017.

9. Banerjee Sudip, and GoyalMeenu, "Performance and Prospects of Mutual Funds With Special Reference To Large Capital Equity Oriented Schemes", Abhinav National Monthly Referred Journal of Research in Commerce and Management, Vol.6, Issue 8, ISSN.: 2277-1166, August 2017. 
10. Bansal Sandeep, "Investors Perception Regarding Mutual Fund and Other Investment Tools", Journal of International Academic Research for Multidisciplinary, Impact Factor 1.393, ISSN: 2320 - 5083, Volume 2, Issue 5, June 2014

11. Vengatesan, K. et al. "Secure Data Transmission Through Steganography with Blowfish Algorithm". Lecture Notes on Data Engineering and Communications Technologies 35. (2020): 568-575.

12. Chalamet. al "Demographic Variables Influencing In the Retail Investors Investment". Abhinav International Monthly Refereed Journal of Research in Management and Technology, Vol.II, 131-138, Nov. 2014

13. Chauhan Pratap M. and Adhav Sunil M., "Recent Trends in Mutual Fund Industry in India", International Journal of Science, Technology Management, Volume No.4, Issue No.4, and ISSN: 2394 -1537, April 2015.

14. Et Bureau, "How to Choose A Mutual Fund Distributors, by Prashant Mahesh, 12th Oct 2017

15. Gandhi R. Kumar and Perumal R., "Mutual Fund Financial Performance Analysis - A Comparative Study on Equity Diversified Schemes and Equity mid Cap Schemes", AMET International Journal of Management, ISSN 2231-6779, Jan - June 2015

16. George Deepthi and ChandranJagadees, “A Study on Women's Preference towards Mutual Fund Investment with Special Reference to Cochin", IOSR Journal of Humanities and Social Sciences (IOSR JHSS), Volume 21, Issue 7, Version VII, Pp. 23-28, ISSN: 2279-0837, July 2016

17. GodaseSaudagar and SenguptaSuchismitaa, "Long-Term Performance of EquityBased Mutual Fund (Systematic Investment Plan)", Twelfth Aims International Conference on Management, ISBN: 978-81924713-8-9, 2015

18. Jacob Tom and Kattookaran Thomas Paul, "Comparative Study of the Mutual Fund Schemes of Reliance and Unit Trust of India”, IRC's International Journal of Multidisciplinary Research in Social and Management Sciences, Vol.2, Issue 3, ISSN: 2320 - 8236, July - Sep 2014

19. Kanodia Monty and KhinchiKiran," Performance Evaluation of Mutual Funds in India: Literature Review”, Everant.Org/Afmj, Account and Financial Management Journal, Vol.2, Issue 09, ISSN: 24563374, Impact Factor: 4.614, DOI: 10.18535/Afmj/V2i9.02, Sep 2017 